\title{
Lead Markets, Innovation Differentials and Growth
}

\author{
by \\ MARIAN BEISE \\ Research Institute for Economics and Business Administration \\ Kobe University, Kobe, Japan \\ April 13, 2004
}

\begin{abstract}
This article suggests that the specialization of countries in the international trade is determined by the lead-lag market pattern of national markets. Many internationally successful innovations have been adopted first in one country while other countries initially either preferred other designs or an established product. A model for the international diffusion of innovations is presented in which nationally preferred innovation designs compete to become a globally dominant design. In this model, there are country-specific market attributes that increase the likelihood that the choice a country makes among alternative technologies is adopted around the world. It is argued that technological knowledge gaps are not the origin of an international competitive advantage. Instead, a country gains a competitive advantage because a specific innovation design was adopted earlier than in any other country. This gives local firms a head start in producing, gather marketing intelligence and securing the property rights of a globally successful innovation. In countries with lag market characteristics, domestic innovations are less likely to get adopted worldwide. They often switch from a domestic innovation design to a foreign innovation design, which increases imports. The lead-lag market explanation of trade specialization has implications for national policies. In this model domestic innovations do not always foster exports; idiosyncratic innovations induced by lag market contexts can hamper the export chances of local firms and in the end lead to an increase in imports. It is suggested that in order to increase exports, national policies have to distinguish between a domestic lead and lag market context in each industry. While in a lead market context, traditional policy instruments that enhance the rate of innovations are effective, in a lag market situation national follower strategies are more appropriate.
\end{abstract}

Keywords: Competing Technologies, International Diffusion of innovation JEL Classification: O33, O38

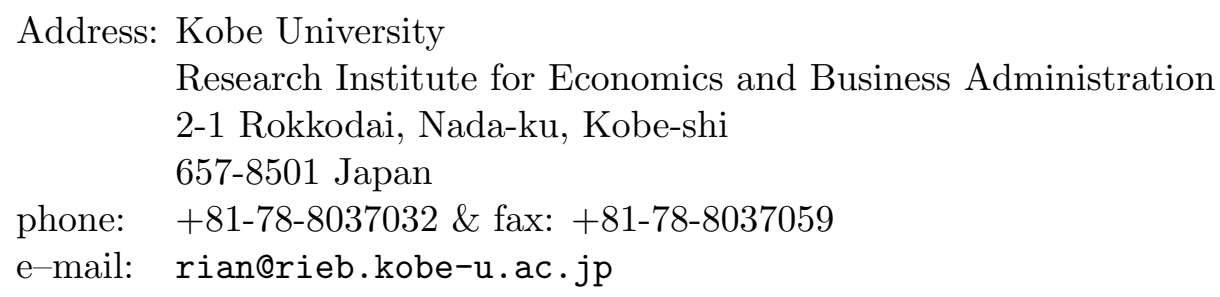




\section{Introduction}

In 1993 the US company Kodak, the largest producer of photographic film, introduced a new film format, the Advanced Photo System (APS). It had invested nearly one billion dollars in research and development and won major camera manufacturers over to developing appropriate cameras that could use the APS film. Before, Kodak had conducted extensive market research to find out what the consumers wanted to have improved. Yet, after years of weak sales, Kodak ceased the production of APS cameras in 2003. Overall, APS was a market failure. In 1995 the digital camera started to appeal to a wider audience and at the end of the 1990s it became apparent that the consumer market in advanced countries would shift to the digital camera. APS was not technically inferior to digital imagery. On the contrary, the quality of pictures of silver halide films is still better than those made by the best digital cameras. However, digital cameras have other advantages such as compatibility with computers. In the end, consumers decided to trade those advantages for lower image quality. Kodak was aware of the potential of digital imagery. In the 1980s, Kodak had invested billions of dollars into digital technology and introduced digital cameras in the US but its market acceptance was low expect for a niche in the professional market. It was perceived that Kodak moved too fast into digital photography, but when digital camera sales suddenly took off, Japanese camera producers were flooding the world market with a vast number of advanced models. Today, Japanese companies dominate more than $90 \%$ of the world market for digital cameras.

The reason for the success of the Japanese camera industry was not a technological knowledge gap but a home market advantage. Initially there was no technological knowledge lead between the US and Japan. Considerable licence payments of Japanese camera producers to Kodak even suggest that Kodak was technologically in the lead for some time. Indeed, most components of digital cameras have been invented in the US, such as the sensor heart of the camera, the CCD (see e.g. Johnstone 1999). The Japanese market turned to digital cameras at relative price levels of digital cameras at which other countries still preferred the traditional camera design. Until 1999 it was worldwide the biggest market for digital cameras. In 2001, it was the first country where more digital cameras were sold than silver halide cameras. The US and the European markets followed in 2003 after prices of cameras plummeted. Since Kodak was not present in the Japanese market with its own cameras, Japanese camera producers had a head start in responding to and interacting with their home market by developing a string of different digital camera models trying vigorously to grasp consumer preferences and improving the models respectively. The interaction process with the market, the cost reduction through mass production, and the learning that has taken place in due course enabled the Japanese companies to be better positioned to offer cameras even in countries where market preferences are slightly different.

The origins of the international specialisation of the industrialized countries are still puzzling. Obviously, countries have gained a competitive advantage in 
certain products. But why has Finland specialized in mobile telecommunications? Why Germany in automobiles, Japan in facsimile machines and the USA in personal computers? It has been suggested before that the specialization of countries and subsequently national growth is a result of differences in the number of blueprints and technological capabilities. Yet, mobile phones were invented in the USA, and the global market leader, Nokia of Finland, used to be a chemical company as recently as twenty years ago. Fax machines were invented in the USA and Germany. At the advent of the computer industry both the US and Europe had equal scientific competence (Bresnahan, Malerba 1999); the first personal computer was even developed in France. It is often difficult to identify international disparities in scientific knowledge and technological capabilities that have originally caused international. The OECD notes already in the 1960s that differences between OECD countries in the scientific capabilities are less marked. Many fundamental scientific findings and inventions originate in Europe. Since then, many case studies, the newest probably Johnstone (1999), have found ample evidence that most successful innovations in the Japanese semiconductor industry have been developed in the US and Europe. In this article it is argued that the competitiveness of nations in particular technologies or products results from a certain context of the home market compared to those of other countries' markets.

While scientific publications, patents and R\&D employees of a country can be counted, market opportunities are hard to measure. It appears, however, that market opportunities are often sufficient to gain international competitiveness if the local market plays a leading role in the world market. Even if technical knowledge diffuses only slowly, companies are often able to utilize knowledge generated in foreign countries. It often takes several years or even decades for new technologies to appeal to the market (Gort, Klepper 1982), enough for most countries to close a scientific knowledge gap. The OECD, like others thereafter, concludes that not inventions but the ability of turning inventions into commercially successful products is a main determinant of an international competitiveness gap (OECD 1968, p. 17). It is not clear, however, why companies of one country would be better able to commercialize new technology than companies of other industrialized countries. Yet, demand for particular technologies and products often emerges in a single country, while the markets in other countries are more reluctant. Market opportunities emerge regionally and firms in the local market often perceive customer needs and preferences first and conduct the most efficient communication with the market. ${ }^{1}$

Historic studies such as Vernon (1966), Franko (1976), Tilton (1971) and the case studies collected in Mowery, Nelson (1999) have indeed found that the

\footnotetext{
1 The home market advantage of firms was first suggested by Linder (1961) followed by Anderson et. (1981), Lundvall (1988) and Fagerberg (1992). It assumes that domestic demand gives local firms an advantage over foreign firms in perceiving local demand preferences and developing innovations because user-producer interaction is more efficient within countries. In management science, customer interaction has been identified as one of the most important success factors of innovation, see e.g. Rothwell et al. (1974), Cooper, Kleinschmidt (1987), Gruner, Homburg (2000).
} 
diffusion of a globally successful innovation from country to country has been induced by a demand gap and that this demand gap has caused a technology gap, which is mostly a productivity gap. Firms in early markets have lower production costs and better products than firms in countries in which demand emerged later. Demand for an innovation normally emerges because of a specific market context that makes an innovation beneficial for local users or cheaper. Yet, it has to be explained why demand in other countries emerges after the innovation has been adopted in a particular country. Keeping in mind that each country is specialized in different product lines or technologies it is difficult to argue that a different willingness to adopt innovations in general can explain the lead-lag market pattern.

The lead-lag market model presented in this article is based on various studies of internationally successful innovations (see Beise 2001). It can be observed that while one country favors an innovation design that later becomes a globally successful innovation early on, other countries initially preferred other innovation variants or an established product based on their particular market context before eventually switching over. It is suggested here that various country specific market attributes can increase the probability that the local technological choice is followed by other countries. A country that prefers a specific technology that later becomes adopted in other countries as well, can be called a lead market, countries that follow lag markets. In this model, export success does not originate from technological supremacy; innovation disparities are rather a result of an international adoption process in which most countries follow the technological choice of the lead market and reduce or abandon their own initial choice. An initial knowledge 'lead' in a technology can therefore not only be insignificant but also be detrimental to competitive advantage, if a country follows an idiosyncratic technological trajectory that it later has to abandon.

In the next section, the article discusses the lead market phenomenon starting with traditional technological gap models. In the following section a simple model of the lead-lag market pattern is presented to demonstrate the various internationalization mechanisms of innovations and the country specific attributes that support the internationalization of locally preferred innovation designs. In the fourth section I discuss the question of how policies can support the competitive advantage of a country given the lead-lag market pattern of innovation success.

\section{From technological gap to adoption lead}

Since the 1980s the idea that "firms worldwide compete in the industrial research lab and that research successes generate competitive advantages that can be exploited in world product markets" (Grossman, Helpman 1991: 177) is common in the innovation and growth literature. It is argued that a country can gain national competitiveness via $R \& D$ activities because new technological knowledge generated by a firm diffuses slower among firms of different countries than among firms located in the same country (knowledge capital as a national public good). As 
knowledge leaks out of the country and is used by firms of other countries as well, the country loses its competitive advantage. The national competitive advantage is, therefore, based on a temporary technological knowledge monopoly. This is the basis of the technological gap theory, first introduced by Posner (1961). Posner assumes that pioneering innovations occur either randomly, out of entrepreneurial vigor, or they are correlated with former innovations and investments which also stabilize the technological lead of a country. It is commonly assumed that scientific advances and basic inventions contribute less to a national technological lead because scientific findings diffuse much faster internationally while it takes longer to transfer them into innovations.

Formal models of knowledge gaps only partly explain the specialization patterns of trade with country characteristics because the set of country attributes that are used is very narrow. National characteristics can explain why a country specializes in $R \& D$ intensive goods in general. Broadly, the higher the endowment with human capital the higher the specialization in R\&D intensive goods (Grossman, Helpman 1991). Furthermore, the size of the market is suggested to facilitate a technology lead because the larger the market the higher the profitability of R\&D. In addition, specialization patterns have been attributed to public R\&D subsidies for selected technologies that governments expected to have a high growth potential, most pronounced probably for Japan (Johnson 1982).

A consequence of the technology gap theory is that all nation-specific factors that are related to the rate of innovations in a country are determinants of competitive advantage. Demand-pull theories since Schmookler's (1966) empirical work suggest that shifts in demand are the main explanation for the firms' growth of inventions. The view that science and demand factors of technical change are interrelated has been widely shared in the literature since the 1980s (see Dosi 1988; Freeman, Soete 1997). Besides its size, the national market is seldom considered as a source of comparative advantage because it is regularly assumed in growth and technology gap models that consumer preferences are equal worldwide, that there is a demand for product variety in every country, or that all companies have equal access to potential users of innovations worldwide. Yet, in the tradition of the home market hypothesis of Linder (1961) several local demand factors have been suggested to increase the innovation rate of a country. While Linder (1961) assumes that increasing income generated the demand for most innovations, others have suggested that the perception of the needs of users can vary from country to country. If successful innovations require close interaction with customers, the ability and the vigorousness of customers to convey their needs to manufacturers increases the innovation output of the manufacturers. So far, Porter (1990) has most prominently stressed the demand conditions in a country as a competitive advantage. He observes that buyers in one country can be more sophisticated and demanding than in any other and that this pressures local firms to come up with innovations. Fagerberg (1995) speaks of advanced domestic users and suggests that customers that operate in a competitive market are more demanding towards their suppliers. Originally, Porter (1990) introduced the idea that competition in a national market increases the rate of innovations. And, indeed, there 
is some evidence that local competition is correlated with export success, even in a country like Japan which is suspected of cartels and governmental intervention (Okimoto 1989, Sakakibara and Porter 2001). In addition, he suggests that the segment structure at home can shape the attention and priorities of a nation's firm. The ability to innovate close to the market needs is the main argument for international competitiveness.

In a similar approach that takes the national market more into account, it was suggested that national growth results from the early adoption and diffusion of new technologies within a country (Hall 2001). Countries that lead innovation and adoption in radical industrial technologies and new sectors drive the growth of the world economy when the innovations diffuse to the rest of the world (Reuveny, Thompson 2004). Indeed, global innovations have regularly been adopted first in one country or region before other countries adopted them (Dekimpe et al. 2000). However, technical progress is not one-dimensional. Some countries adopted new technologies that failed on the world market. In contrast to the common perception of globalization, in most industries market conditions and preferences do vary considerably from country to country. Countries usually have different environmental conditions, different needs, different preferences, different prices of goods and factors. A firm that intends to export normally has to adapt each product more or less to the foreign market conditions. One of the biggest challenges of a multinational firm is to develop a globally standardized product. Although multinational firms aim to develop global innovation designs, few have succeeded (see the global marketing literature such as Kotabe, Helsen 2001, Johansson 2000, Cateora, Graham 2002). Globally successful innovations are frequently not the result of a firm's product development efforts but the result of a process of international standardization that often had not been predicted or even intended.

Innovations are induced through increases in the incomes of potential users, environmental conditions and price changes of goods and factors (Binswanger, Ruttan 1978). Therefore, initially, the global diversity in market conditions generates a variety of innovations and different designs of innovations. An innovation design is a technical specification of an innovation idea. Different designs of an innovation have similar functions but different appearances, use different technologies or complementary goods, and have a different mixture of attributes such as size, quality performance, precision, energy consumption, etc. (see Utterback 1994, p. 18). For instance, the facsimile machine and the teletypewriter are distinct innovation designs of a communication device for transmitting pictorial information. An Apple personal computer and an IBM mainframe computer are different designs of a computer. Mobile cellular telephony, satellite systems and pagers are different designs of mobile communications. A Cadillac and a Mercedes are two different designs of a luxurious car. Different designs can often not be distinguished by technological superiority or quality. They are all hightech, but they have their advantages and disadvantages depending on the regional conditions. Facsimile machines have advantages in countries with pictorial letters such as Japan, while the teletypewriter is superior in countries that use the 
roman type. Satellites are ideal for countries with low population density such as the USA compared to cellular systems which have their highest merit in the European population density.

Countries favor different innovation designs because of differences in the environmental context or because of different social contexts and traditions. Sociologists speak of the social shaping of technology (MacKenzie, Wajcman 1985). For instance, it was suggested that personal computers, having no real technological advantage over mainframe computers, invaded large companies in the US in the 1980s through the back door because the engineers were more individualistic compared, for instance, to Japanese ones, who were happy to share a large computer with their colleagues (Freiberger, Swain 1984, Ceruzzi 1996). Innovations are induced by local market contexts even in industries that are seemingly global in nature. A historic example of the effect of regional market context on innovation designs in the aircraft industry is given by Cateora and Graham (2002: 382): "American manufactures [of jet aircraft] built the engines slung below the wings whereas the British competitor built the engines into the wings. The American design made for easier access and saved on repair and servicing costs, and the British design reduced aerodynamic drag and saved on fuel costs. Both designs were high quality for their respective markets. At the time labor was relatively expensive in the United States and fuel relatively expensive in the United Kingdom." A recent example is given by Porter (1990), who notes that the innovative Airbus design was induced by the European geographic context. Regulation, laws and traditions shape innovations as well. The pharmaceutical industry, for example, faces varying markets from country to country. The market context is a complex system of users' perceptions, mediators and institutions. In Germany, physicians are traditionally educated in herbal medicines and often prescribe them in contrast to the fixation on pharmaceutics in the US. In the traditional Chinese medicine, treatments and substance mixtures are used that are rejected in the western world. Furthermore, the health care system and the cooperation with clinical personnel is differently organized which leads to different new pharmaceutical products and medical equipment.

A consequence of globalization is that nationally preferred innovation designs are available instantly on the world market and compete against each other. Many countries offer innovation designs on the same technological and quality level. There is often no technologically better design. Competition between innovation designs occurs on different levels. For instance, the European cellular telephone standard GSM competes against other cellular mobile telephone standards as well as against pagers and satellites. As different designs of a nuclear reactor compete, so does nuclear energy compete against wind energy. The term designs of an innovation used here, therefore, encompasses all technologies that can be more or less substituted with each other, and includes not only tangible technical products but also software, the formula of a soft drink, a technology or even a technological trajectory. For instance, Denmark has chosen a distinct technical development path from generator generation to generator generation, starting with small generator types in the 1980s to bigger ones in the 1990s (Beise, 
Figure 1: International Diffusion of Competing National Designs

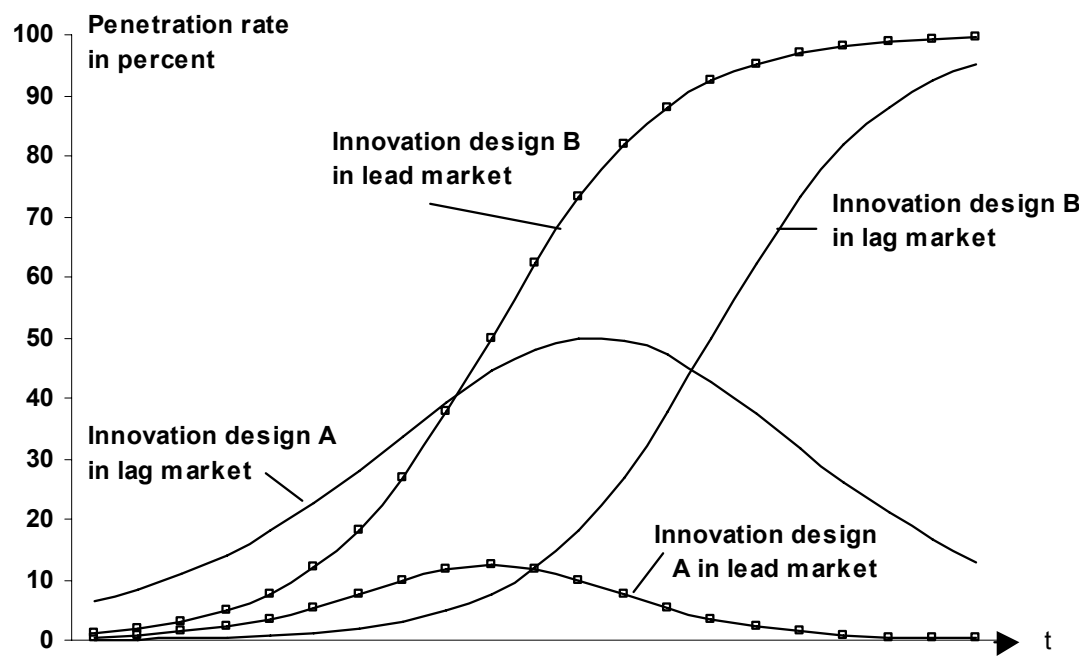

Rennings 2003). Innovation designs compete not only against other innovation designs but also against traditional designs that are incrementally improved. For instance, in the automobile industry the fuel cell-powered car envisioned as the next generation competes against hybrid cars as well as improved combustion motors (Beise, Rennings 2004).

The observation that globally standardized products and processes exist, however, does not imply that preferences are equal. The competition between nation specific innovation designs and between innovation designs and established products can lead to the emergence of dominant designs ${ }^{2}$ as well in the way that country after country adopts or switches over to the same design out of economically reasonable motives. In studying several successful innovations I have found that countries that are late in adopting a specific innovation design that becomes a global success often do so because they have first preferred a different design. Figure 1 depicts a stylized international adoption pattern with competing innovation designs in which one design emerges as a globally successful innovation. Despite adopting an innovation design earlier than the lead market, the 'lag' market switches over to the lead market design. An example is the competition between the facsimile machine and the teletypewriter (figure 2). According to Peterson (1995), technological knowledge in fax technology was equally distributed among the United States, Japan and Germany in the 1980s and early products from these countries were equally advanced. Yet, the fax machine started its huge market success in Japan long after it was introduced in the western market; it was initially rejected because the teletypewriter was considered as more appropriate.

Globally dominant innovation designs, therefore, mean that the market context of one country has shaped the world market. The lead market concept of

\footnotetext{
${ }^{2} \mathrm{~A}$ dominant design is defined as a design that is adopted by a majority of users (Utterback 1994, p. 24) and a global dominant design is the design that is adopted by most countries, in contrast to national dominant designs, that are only widely adopted within a country.
} 
Figure 2: Competition between fax and teletypewriter

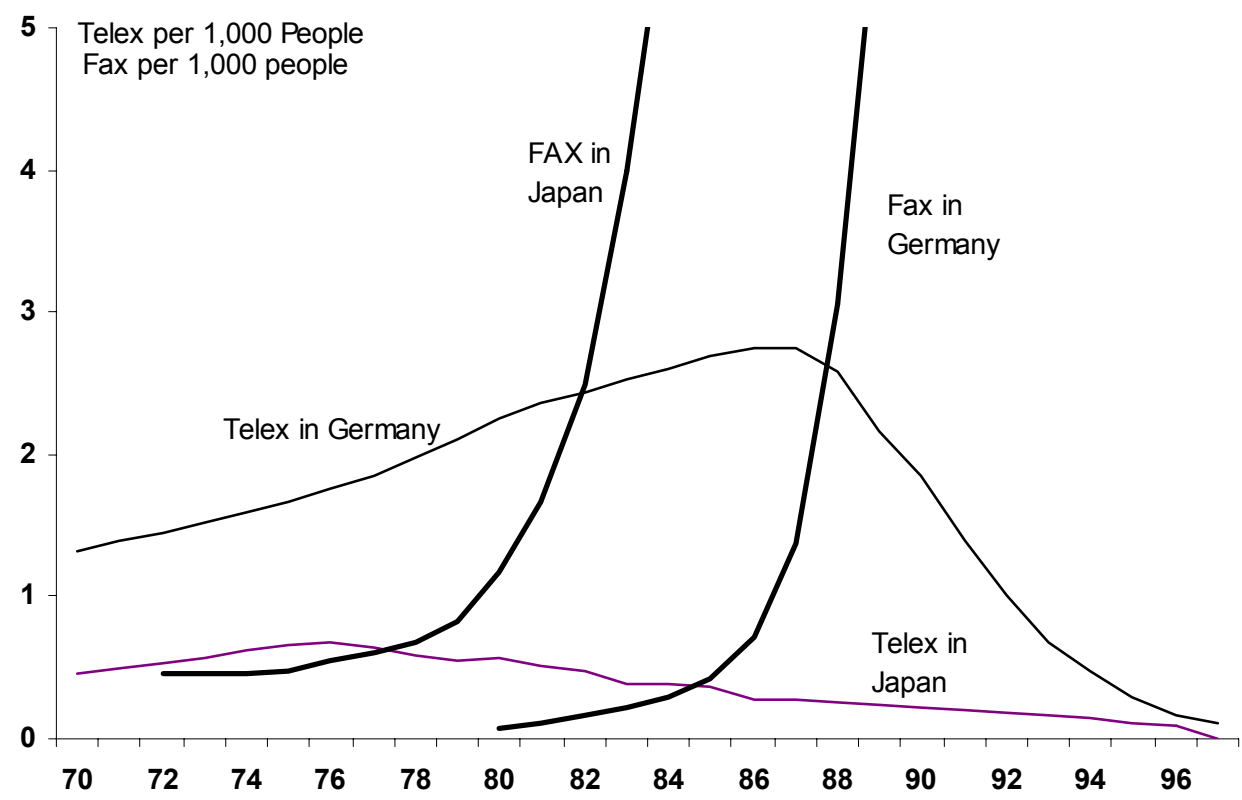

Source: ITU, Scherer (1992), Yoffie (1997)

technology reads failures of innovations as having been induced by lag markets. We can even go further: When an innovation fails to substitute an established product (for instance synthetic leather failed to substitute leather, see Freeman, Soete 1997), then countries that opted for the established product and rejected the innovation can be interpreted as lead markets in the sense that their initial technical choice prevailed on the world market. A more general definition of lead markets is a market whose technical choice is followed by other countries.

In the next section, the reasons why local technical choices are followed by other countries are discussed in detail. It is suggested that certain characteristics of regional market conditions increase the probability that the technology choices a country makes on the basis of its market context for a particular product line become internationally accepted.

Firms in the country that first adopted the globally dominant innovation design garner a competitive advantage because they have a lead in gathering designspecific knowledge: Knowledge about the product and manufacturing technology, knowledge about user preferences and applications. In addition, specific innovation designs can be better protected by patents and trademarks than basic technological knowledge that can be used to developed various specific designs. For instance, all cellular mobile systems are based on fundamental technical principles invented by the Bell labs. These technical fundamentals are not proprietary in contrast to the specific systems that have been derived. The worldwide success of the GSM mobile system, however, entails that manufacturers have to offer GSM compatible equipment by following its exact specifications. Companies that did 
not participate in the development of GSM have experienced higher costs than their competitors (Beise 2001).

Lag markets are disadvantaged in many respects. Countries that have initially preferred a different innovation design (or an established design) than the globally dominant design not only fail to export their own innovation design but are also in danger of losing their home market to the foreign innovation design, a situation which entails increased imports. Countries that switch from one design to another have to bear the switching costs (Klemperer 1987). Investments in $\mathrm{R} \& \mathrm{D}$, infrastructure and training for the development and implementation of idiosyncratic designs represent losses and hamper the adoption of the innovation.

It is argued here that the origin of competitiveness of a country is not the number of innovations a country generates or that a specific innovation is preferred and adopted early, but that the same innovation design that is nationally preferred becomes adopted worldwide. Yet, technological capabilities are not insignificant for competitiveness. A condition for competitiveness is that companies keep track of new technological knowledge and are able to utilize technical knowledge and scientific findings generated abroad. This commonly requires their own research activities that are the basis for an absorption capacity (Keller 1996).

The hypothesis of lead markets neither disputes science-push theories of technical change nor is it a pure demand-pull theory itself. It argues that technical advancement is not the origin of national competitive advantage in many product domains. Lead markets exist even if technical progress overall is mainly based on scientific advance. Some science-push theories consider the market as being reluctant to adopt new technology. The market has to be persuaded to accept new technology. If so, local markets can be more or less reluctant to adopt a technology that will prevail on the world market later because of its technical advantage. Companies in the most willing market get an advantage even if they have not generated the technological knowledge. Second, if producers are not (perfectly) informed about demand preferences, but innovate instead on the basis of scientific findings alone, demand does not induce technical change directly but rather selects the technology within a variety of innovations during the diffusion process. Users will select the variant that fits their purposes best - or is "the lesser of the various evils on offer" (Grupp, Maital 1998, p. 74). If demand and environmental conditions vary, the benefit of technology alternatives may differ from country to country and different alternatives might fit local conditions best. As a result, users in one country will select a different technology than users in other countries. If demand conditions in one country are highly idiosyncratic compared to other countries, it is likely that demand would at least 'bend' the technological progress of local firms towards an idiosyncratic direction, if not in the invention phase then in the diffusion phase.

After a new innovation is successfully commercialized in a specific national context it has to overcome international differences. It has to prove that it is profitable in other market contexts as well. In the next section a simple consumption model demonstrates why countries follow another country in adopting a specific innovation design that it has initially rejected. 


\section{A model of lead markets}

The lead-lag market pattern of adoption of innovations can be explained by a variety of mechanisms. This makes the theory of lead markets eclectic. Rather than concentrating on one mechanism that could be the most important one, I would like to demonstrate the variety of possible mechanisms in a simple consumption model.

Let us consider two countries that initially demand and prefer two different product designs which have the same general function so that they compete on the world market. The two designs represent two different designs of an innovation, or an established product and an innovation that was introduced in order to substitute the established design. Both designs are available in the two countries and reflect state-of-the-art-technology. ${ }^{3}$

In this model it is assumed that both countries have the same general willingness to adopt an innovation. Firms respond mainly to their home market context. They can get access and utilize state-of-the-art technology generated worldwide. As a result, countries can only gain a technological lead in the form of market and production knowledge of a specific innovation design and after they have masscommercialized it. Lastly, national preferences are neither totally equal nor too different, so that they can be overcome by the advantages of a global standard.

In the first stage of the model, the two countries adopt a different design, which means each design has a large market share in one country and a low market share in the other. This means that different properties of a product are preferred in each country. Different consumption patterns can be a result of (1) different prices of the designs in the two countries, (2) different budget constraints, and (3) different benefits of the two designs in each of the countries. The benefit of a design is determined by the environmental context, traditions and taste, or local network externalities. In the second stage, both countries prefer the same innovation design. There are three general mechanisms that could cause the other country, the lag market, to change its adoption pattern: (1) the relative price of the design preferred in the lead market could have decreased in the lag country, (2) the available budget of users in the lag country could have increased and (3) the relative benefit of the design adopted in the lead market for users in the lag country could have increased.

The first mechanism, a relative price reduction of the design preferred in the lead market for users in the lag market, shifts consumption in the lag market away from the previously preferred design towards the design preferred in the lead market. This price mechanism can be further divided into two sub cases. First of all, one innovation design becomes adopted by both countries if the price of the design preferred in the lead market decreases in relation to the prices of designs

\footnotetext{
${ }^{3}$ The innovative design is therefore not an upgraded established product; it is a new technical specification that competes against the constantly upgraded established product. Several authors suggest the term radical innovation for these innovations, but I prefer the neutral term design because of its non-normatively and because the term radical innovation is used in industrial economics in a different context.
} 
Figure 3: Price reduction and global adoption of the Fax machine

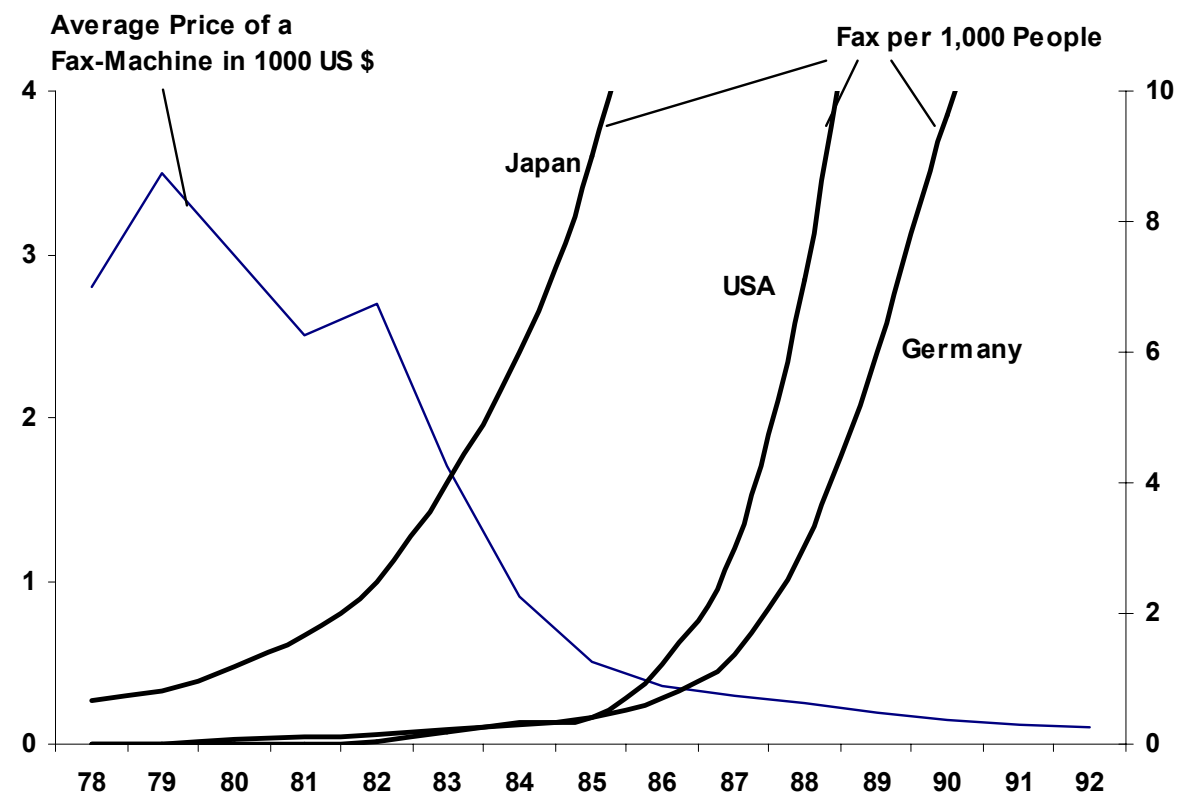

Source: ITU, Economides, Himmelberg (1995)

preferred by the other country. This price reduction effect is the main argument of Levitt's (1983) famous "globalization of markets" hypothesis. He asserts that global producers "attract customers who previously held local preferences and now capitulate to the attractions of lesser prices". The price of one design decreases faster than for the other when the lead market is larger in an early stage of the product life cycle, allowing manufacturers to exploit larger economics-ofscale. When economies of scale and learning effects are big, countries with a large internal market for a specific design have a lead market advantage. Scherer (1992) notes that when the fax machine was a market success in Japan, Japanese manufacturers were able to exploit economies-of-scale and lower the price to levels on which it became successful in western countries (figure 3). Consumption of an innovation can also be higher in a country in which the price level of the innovation is the same but that of other goods is higher than in other countries. For example, consumers in Japan purchase more expensive consumer electronics and cars because even affluence does not enable the purchase of a family house in metropolitan areas (Tsuru 1993, p. 169).

In the second case, the price of the lead market design is initially lower in the lead market than in the lag market, but over time the design becomes available for the lower price in the lag market as well. In this case, the lead market anticipated future world market prices (figure 4). This has happened in the mobile telephony case. Cellular phones were much cheaper in the Nordic countries in the 1980s than in any other country. In the 1990s, however, liberalization of the telecom sector sent prices down worldwide, making cellular phones affordable for a wide 
Figure 4: Price anticipation in the lead market

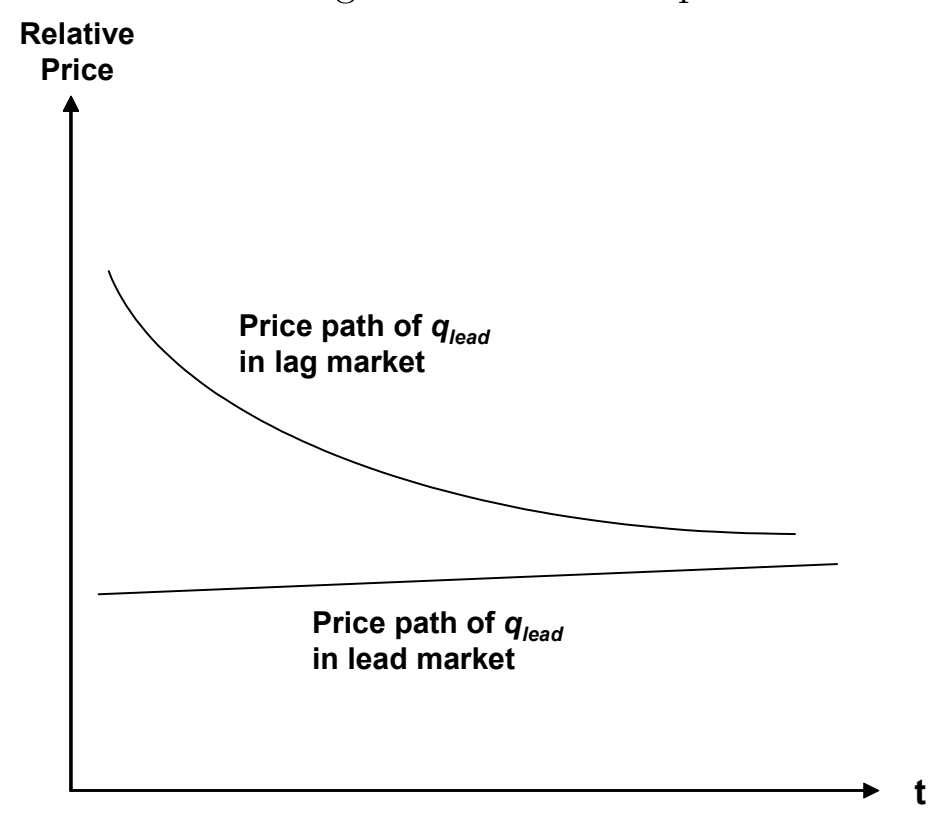

consumer group. ${ }^{4}$

Increasing income is another diffusion mechanism for innovations and it is the main explanation given in the classical international product-life-cycle theory by Vernon (1966). Many commercially successful innovations were developed in the United States because the per-capita-income in the United States was the highest in the world and the rising middle class established the demand for convenience products (Franko 1976). As other countries caught up and reached the previous levels of per-capita-income of the US, demand for the same new products emerged in these markets as well. Per capita income has indeed been frequently empirically proven to have a positive effect on the rate and time of adoption (see the literature review by Dekimpe et al. 2000b). Nowadays, however, this effect seems to be not as relevant as it was before the 1970s, since per-capita-income converged within the industrialized countries. However, for selected users markets it can still be relevant. For instance, the disposable income of the youth, the elderly, or chronically sick considerably varyies internationally. In addition, decreasing income (e.g. pensions) can generate demand for substitution goods.

The third internationalisation mechanism is when the benefit of a design for users in the country that initially preferred the other design increases relative to the preferred design. The benefit can increase due to an international trend or the ability of a country to influence other countries into adopting the same innovation design. ${ }^{5}$ Countries at the forefront of an international trend anticipate demand

${ }^{4}$ For a detailed account of the history of mobile cellular telephony see Beise (2001)

${ }^{5}$ We do not consider the case in which technical improvements drive one design to become the global dominant design. It is assumed that both designs are open to the same technical improvements that are realized when a design is adopted. Therefore, there are no disrup- 
that will later spread worldwide. A lead market, therefore, has anticipatory buyer needs (Porter 1990). It is also the main explanation of lead markets for Bartlett and Ghoshal (1990, p. 243): "Local innovation in such markets becomes useful elsewhere as the environmental characteristics that stimulated such innovations diffuse to other locations". This points to an external trend, such as a global demographic, social or environmental trend, but preferences in the lag market can be directly influenced by the consumer choices of users in the lead market as well. For instance, an adoption reduces uncertainty about the benefits of an innovation design. The demonstration effect was long identified as an important mechanism of diffusion (Mansfield 1968). Potential adopters in a lag country observe the success of the innovation in the lead market, and this spurs adoption of the same design in the lag country, even if the design is potentially not the best for the lag market. Reputable first adopters of an innovation signalling the credibility of a specific innovation design can further reduce the risk of adoption.

On the other hand, it could be argued as well that the preferences in a lead market are shaped by the environment in foreign markets, making the innovations that are preferred in the lead market more appropriate for foreign markets. Local market participants might want their innovations to be useful in foreign countries as well because that would make their use cheaper. Users as well as competitors, suppliers or banks could pressure local firms into developing innovations that can be exported by incorporating features that enhance the product's compatibility with foreign environments. A country in which the market supports the export orientation of local firms can, therefore, constitute a lead market as well because the market increases the chances that local innovations are adopted in foreign markets. Examples are the preference of Telecom Sweden to adopt equipment that can be exported, compared with the doggedness of the telecom operator in Japan, NTT, to stick with idiosyncratic standards that hampered Japanese exports in the telecommunication equipment sector. In contrast, in the 1970s the Japanese government supported the export chances of the Japanese automobile industry when the US regulation for vehicle emissions was introduced a year earlier in Japan than in the US (Beise, Rennings 2003).

Relaxing the assumption of the consumption model of perfect information on user preferences leads to an additional argument for the internationalization of national innovation designs. Often, preferences are not perfectly known either because users are not aware of or do not effectively articulate their preferences. In this situation companies test the market with alternative innovation designs. The more alternatives offered the higher the likelihood of finding the technological design that is the most beneficial and the larger the variety of new applications of an innovation. This implies that differences in the competitive climate in countries can lead to different consumption patterns, even if the underlying preferences are the same internationally. For instance, in a country with a monopolistic producer or user, fewer alternative designs (or only one) are offered than in a country where

tive technologies (Christensen 1997) that become adopted in all countries because they just happened to improve faster than the other design. 
several companies compete. Competitive markets are, therefore, more likely to discover latent needs and innovation designs that meet the preferences best. If preferences vary from country country, the initial consumption pattern might not reflect the local preferences when too few alternatives are offered in the market in order to determine the locally most beneficial design. Fierce competition in one country may then lead to the discovery of an innovation design that is even more beneficial for users in other countries than the best among the locally offered designs in those countries. A country with more local competitors or tougher competition is therefore more likely to find a design that is the most beneficial to both itself and many other countries as well. Local competition has already been suggested as enhancing international competitiveness; in the lead-lag market context presented here, national competitiveness is not directly caused by the number of innovations generated in the country but by the more efficient revelation of preferences in the country.

A fourth possible lead market explanation can be derived from the process theory of internationalization. Johanson and Vahlne (1977) observed that after an innovation has been successful in the home market most firms start the internationalization of the product by introducing it in those foreign markets that are most similar to the home market in terms of preferences, per-capita income and environmental context. Firms often find that they can introduce the same product successfully in those markets with only minor adaptations. In general, this means that the more similar the context of a country is to other countries, the more it can export. In the two-country model presented above, none of the countries would gain an advantage through trade to set the standard. If the size of the two countries is the same, both would export the same amount to each other. However, adding another country shows that the similarity of each country to each other can effect national competitiveness. If the degree of similarity between each pair of countries is different, then exports of each country would be different as well. The country for which the sum of similarity to the other two countries is smaller would export more. For instance, assuming that only one preference dimension such as product size is important for users, the country were an average product size is preferred would export more than the countries which prefer smaller or larger product sizes, since the trade between the countries that prefer more extreme choices would be small. The country in the middle with the highest exports would, therefore, gain advantages via global network effects and economies-of-scale and, therefore, be better positioned to set an international standard than the other two countries.

If we assume that the choice of a user for a product can be fully modelled with $n$ product attributes, reflecting the preferences and price situation, each country's preferred design can be positioned in an $n$-dimensional space and the similarity between the two countries' choices can be quantified using a distance measure. The total weighted average distance of one country to all other countries is negatively correlated with the exports of that country. There would be countries with extreme design preferences and countries that lie in the middle between extreme choices. Countries whose market choice lay in the average of all preferred 
designs are thus expected to have the best export performance and, therefore, the highest lead market advantage.

In this scenario, unlike the attributes of a lead market discussed above and unlike suggestions in the literature, demand in lead markets is not characterized by extremes but by the average of product characteristics. The lead market is not the country in which the highest quality, the smallest or the most features are demanded. In contrast, extreme product requirements make a country an idiosyncratic market in which products are adopted that are too expensive or "over-engineered" for other countries. Examples can be found in the investment goods industry in which extreme local quality requirements sometimes hamper exports. In Japan, consumers pay high prices for high-quality food products that few outside Japan are willing to pay.

At least two of the country characteristics that have been deducted from the lead market model that increase international competitiveness of a country have been already suggested before: the size of a country and the degree of competition. The lead market model adds several country attributes. Furthermore, the lead market and the common theories of international competitiveness lead to different policy conclusions. In the next section, the policy implications of the lead market model are discussed.

\section{Lead Markets and Technology Policy}

Traditionally, governments see their role in strengthening the stream of innovations generated in a country and in supporting a new technology to overcome the initial impediments to commercialization. However, a new technology normally has to overcome two hurdles for international success. It has to become successful in one market context and, second, it has to overcome the differences among countries. Often, governments focus on the first problem and in doing so worsen the second problem. They intervene in the local market in order to make a specific technology more attractive, but by doing so widen the differences between the local market and all other countries' market contexts. For instance, introducing regulation or subsidies that favor the local adoption of a particular innovation increases the local success of the innovation but at the same time makes the local market more idiosyncratic. An idiosyncratic market is less likely to be followed by other countries, unless other countries introduce the same policy instruments. 6

While the former models of innovation and trade lead to the conclusion that in order to improve the competitiveness of a country, the government should provide incentives for the generation of technology in general, the lead market model

\footnotetext{
${ }^{6}$ Another lead market mechanism that has been omitted in this paper but that is relevant for many innovations in regulated industries is international policy diffusion (see Kern et al. 2000, Beise et al. 2003). An innovation design becomes a global design if a policy instrument that has induced an innovation design in one country is adopted in other countries as well. For instance, the catalytic converter became an international standard because the emission standards have eventually been adopted in most other industrialized countries.
} 
suggests that not all innovations enhance export performance. It distinguishes innovations by their likelihood to be subsequently adopted in foreign countries. Locally-induced innovations are more likely to be exported in considerable quantities in those industries or product lines in which a country has a high lead market potential. In industries in which a country is a lag market, it is not only unlikely that indigenous innovation designs can become successful internationally, it is also possible that over time the indigenous innovation designs are squeezed out by the design favored in the lead market. Incentives for indigenous innovations can, therefore, have a negative effect on a country's competitiveness. In a lag market context the adoption of locally preferred innovation designs would lock a country into an idiosyncratic technology and delay the adoption of a global standard.

It would be, therefore, highly beneficial for a country to support not only the generation of scientific knowledge and inventions, but also its lead market role. The lead market theory suggests that there are attributes that facilitate the lead market role and which could be strengthened. For instance, governmental policies can strengthen local competition and the export orientation of the local market. Export orientation can be strengthened by making information on foreign market preferences available, setting regulation that is similar to other countries' regulations and a procurement policy that prefers technologies and innovations that can be exported and avoids highly nation-specific designs. National legislation and regulation tend to focus on domestic needs and the local environmental context. Often this policy does promote the adoption of technologies that fit domestic context best regardless of the benefit for other countries. Porter (1990, p. 645) stresses that government specifications "should be set with an eye to what will be valued in other advanced nations". By actively anticipating the requirements for the context of foreign markets and including them in national regulations and procurement, idiosyncratic country-specific innovations can be avoided. For instance, state-owned firms and government agencies can demand that firms develop exportable innovations instead of demanding innovations that fit the national context best. Promoting the export orientation of domestic firms can mean sponsoring a design that takes account of demand preferences abroad. Global trends can also be utilized to support the lead market role of a country. If a factor price or the price of a complementary good such as infrastructure is marked by a global trend, a government can try to increase the domestic price level of the factor or the complementary good by raising specific taxes (in the case of an increasing trend) or decrease the price by lowering taxed or giving subsidies (decreasing trend) and therefore push a country to the forefront of the trend.

Governments, of course, always meant to create a lead market by supporting the generation and adoption of new technology. A traditional approach is to generate early demand through state-owned companies or direct subsidies for the adoption of a specific innovation design. The aim is that a subsidized domestic market would initiate mass production and drive down the production cost through economies-of-scale and scope. The reduced cost would then enable the new technology to become internationally successful. This price reduction effect 
was indeed described as a lead market mechanism. However, there are several problems with a strategy that solely aims at cost reductions and neglects the other lead market factors.

First of all, potential cost reductions are often too optimistic and not sufficient. Examples of global innovation designs that have become successful because of their low prices demonstrate that the price has to come down a long way before it dominates in foreign markets. In recent cases of environmental technology such as photovoltaic energy and the fuel cells, the cost reduction estimations have often been exaggerated (Beise and Rennings 2004, Beise 2004). Governments often target a particular industry or technology that is expected to have a high growth potential but in which the country is a lag market.

Second, policy instruments favor specific designs that might not be applicable in other countries. The government as a user, however, has different preferences and cannot simulate a market selection process. Often, the government selects a technology on the basis of its own preferences such as high growth potential, high employment effects. In contrast, information about the best design in a market context is mainly embodied in a market interaction. This often means that the government is "backing the wrong horse" (Cowan 1990). Third, foreign governments might react negatively. Public subsidies aimed to stimulate exports regularly ensue the negative reactions of foreign governments which then could try to block the adoption of the technology in their countries.

An example for governmental intervention that went wrong is Minitel in France. Minitel is an information retrieval service that was tremendously successful in France (Kramer 1993). When the socialists came to power in 1980, France adopted an even more interventionist industrial policy than before. They nationalized the electronics and telecommunications industries and merged them into a few large corporations. R\&D expenditures rose and a new technology was introduced and publicly subsidized to spur adoption. The General Telecommunication Agency (DGT) sought new forms of communication and new products. Possible offspring from the marriage between telecommunications and computing like teletex, electronic mail, pay-TV, telepayment, and home banking were supposed to be pursued and adopted early in France. It was thought that the technological advances in France would make it possible to export French technology. Minitel was one of the technologies implemented by French governmental agencies where the adoption was highly subsidized. Yet, corresponding systems in other European countries (like BTX in Germany) were not successful either. Instead the Internet, an open non-proprietary technology, became the globally dominant design for information systems. Minitel's early lead even turned out to be a disadvantage for France because for a long time the adoption of the Internet was very slow in France (DTI 1999, p. 28). As late as 1997 France only had 4 Internet hosts per thousand inhabitants compared to an OECD average of 15 and the figure was much lower than in most industrialized countries (OECD 1997, p. 58). In the competition between different designs, the Minitel system architecture reflects the French market situation of a state-owned telecom provider that sets up and controls a data network, while the Internet reflects the principle 
Figure 5: Competition between Minitel and the Internet

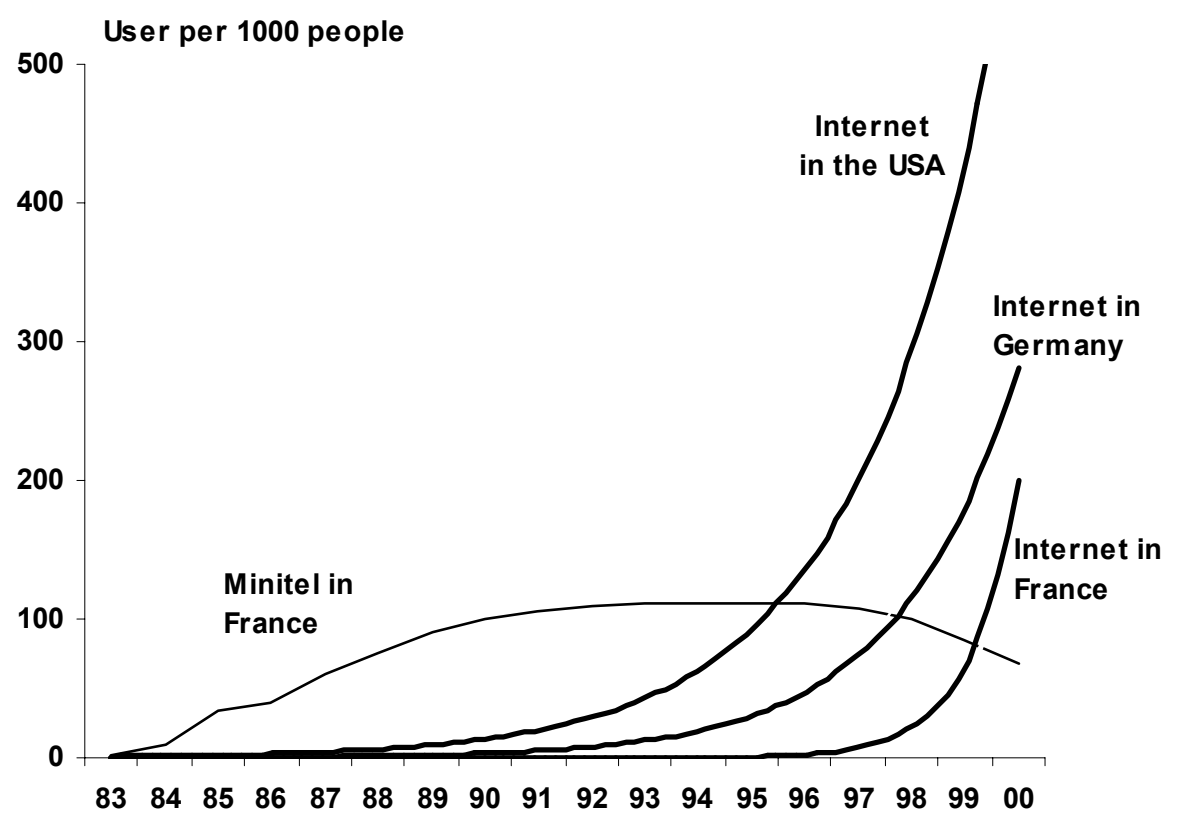

Source: ITU, Berne (1996), own estimations

of interconnection of different networks without a controlling center. The Internet architecture proved to be more complementary for global adoption. The US was the lead market in that it provided the highest incentives for users in other countries to adopt it.

A lag market role of a country, however, does not always mean that the country cannot be competitive at all. The lead market model only suggests that the technological design that is preferred locally is not internationally competitive. Yet, a lag market can gain a competitive advantage if it deliberately abandons its preferences and follows a lead market quickly in adopting the innovation design favored in the lead market. Lag market firms can often transfer and use technology from the lead market, monitor the dynamics in the lead market and and participate in learning processes in the lead market and ultimately imitate the lead market design. Japanese companies have often adopted a fast-follower strategy when the local market has willingly accepted the lead market role of foreign countries. Anticipating the local market disadvantage, they have built up the capability to quickly adopt the technology choice of large western markets and to focus their technical skills instead on superior production technology and service in order to gain a competitive advantage over the lead market firms. For instance, while most product innovations in the automobile industry emerge from the European and the US market context, Toyota has developed a legendary superior production system that is until today unmatched by competitors (Womack 1990).

In industries in which the country is a lag market, a fast follower strategy can 
be more appropriate than a policy that aims at creating a lead market context. This, however, requires that the market participants not insist on the technical specifications that would be ideal for the local market context but that are idiosyncratic in an international context. Technology policy can support a lag market by helping the country's users and manufacturers to swiftly follow the lead market and by lowering the responsiveness of local firms to the local idiosyncratic demand. Governmental policies, regulation and procurement could strengthen the orientation of local firms on the lead market. National technology policy can encourage cooperation between domestic firms and firms in the lead market. Regulation and public procurement should be open to or even be biased towards technological designs popular in the lead market. An example for this strategy is the Japanese telecom operator NTT. After the Japanese mobile telephone standards failed to be successful outside Japan, the Japanese operator participated in the development of the 3rd generation mobile system in Europe and was the first to introduce the new joint standard in the Japanese market. This gave local mobile phone manufacturers a head start in commercializing the appropriate network technology and mobile phones.

The lead market model suggests that technology policy can be differentiated according to a lead and lag market role of the country. Taking the limitation to create lead markets into account, a government could try to identify industries in which a country has already lead market advantages and shift public research funds to research programmes that support innovations in these industries. In lag market industries, instruments are more appropriate that support the fast following of a lead market.

\section{Conclusions}

It is suggested here that an important determinant of the specialization pattern of an industrialized country is the lead-lag market characteristic of each industry of a country. Countries are specialized in industries in which the domestic market context constitutes a lead market role. Countries are less specialized in industries in which the country has lag or follower market characteristics. Although not all industries are characterized by a lead-lag market pattern, a lead-lag environment has a high impact on specialization, trade and growth because countries can gain dominance in a particular product line. Cellular phones had a tremendous impact on the specialization pattern of Finland, as had computers on that of the US and automobiles on Germany's pattern.

The lead market role ensues an international competitive advantage for a nation because domestic firms can gain a productivity and market intelligence lead over firms in other countries for internationally successful innovations. A lead market gives domestic firms a head start in terms of learning, economies-ofscale, quality improvements, setting up distribution systems, access to supplies, brand loyalty and international reputation, product line differentiation and longterm market share (Robinson, Fornell 1985) for a particular innovation design. 
Lead markets "catalyze" (Porter 1990, p. 614) the international success of a domestic firm's innovation activities.

Lead markets demand innovations that subsequently become the preferred choice of foreign markets as well. Yet, the lead market characteristics discussed in this article only enhance the likelihood of an international success of a domestically successful innovation. They do not necessarily increase the domestic success of innovations. It might not be easier for firms in the lead market to commercialize innovations. But once they have tapped the local market with an innovation success, export activities are easier than for firms in countries with a more idiosyncratic taste for innovations.

An idiosyncratic market is a disadvantage for domestic firms since the local market demands innovation designs that cannot be easily exported. Over time local innovations risk being squeezed out of their home market by foreign innovation designs. Lead markets are therefore associated with exports while lag markets induce imports. As a result, the lead-lag characteristics of local markets have implications for growth. It can be expected that the overall growth of a country depends on the lead-lag market structure of its economy. A country's growth depends on the growth of industries and the lead-lag market role of the domestic market in these industries. A country has formidable growth perspectives if it has lead market characteristics in fast-growing industries, whereas leading in stagnant or shrinking industries makes a dent in domestic growth. On the other hand it is also possible that the lead market role of a country increases the global growth of an industry. Thus, growth is endogenous. Lead markets often open a mass market in industries where only a niche market has been expected before. A mass market can be enabled by low prices or technical specifications or new applications of a technology. For instance, until the 1990s mobile telephony was seen as technology limited to a small group of users. In the Nordic countries, however, a broader market was sensed, targeted and made possible by lowering the prices and enhancing the technology to accommodate more users (Beise 2001). In Japan, the use of facsimile machines was widened by the public endorsement of faxed official documents.

It can be observed that lead markets are rather persistent over a long time. It could be argued, though, that while the lead market role is lasting, the competitiveness that emerges from the lead market role ends when production is moved abroad to countries that offer better factor conditions. It is true that cellular phones, personal computers and digital cameras are increasingly produced in low cost countries outside the respective lead markets. However, the industry leaders such as Dell, Nokia and Canon still employ a large workforce at their home countries. While production can often be outsourced to specialized manufacturers, the lead market role of a country requires a firm to keep the marketing, engineering and management functions in the lead market.

It is therefore of vital interest for countries to identify their lead and lag roles within the industry structure. In lead market industries, research and development to generate indigenous technologies are expected to increase exports while in idiosyncratic lag markets, local firms should refrain from responding too much 
to the local market and seek to follow the lead market abroad.

\section{References}

Aitken, B., G.H. Hanson and A.E. Harrison (1997): Spillovers, Foreign Investment, and Export Behaviour, Journal of International Economics 43, 103-132.

Anderson, Esben S., Bent Dalum, Gert Villumsen (1981): International Specialisation and the Home Market - An Empirical Analysis, Industrial Development Research Series No. 19, Research Report, Aalborg University Press.

Audretsch, David B. (1995): Innovation and Industry Evolution, Cambridge: The MIT Press.

Bartlett, Christopher A., Sumantra Ghoshal (1990): Managing Innovation in the Transnational Corporation, in: Bartlett, Christopher A., Yves Doz, Gunnar Hedlund (eds.), Managing the Global Firm, London: Routledge, pp. 215-255.

Baumol, William J., John C. Panzar, Robert D. Willig (1982): Contestable Markets and the Theory of Industry Structure, New York: Harcourt Brace Jovanovich.

Beise, Marian (2001): Lead Markets: Country-Specific Success Factors of the Global Diffusion of Innovations, Heidelberg: Physica.

Beise, Marian (2004): The International Adoption of Photovoltaic Energy Conversion: Is Japan a Lead Market?, RIEB Discussion Paper No. 153, Kobe.

Beise, Marian et al. (2003): The Emergence of Lead Markets for Environmental Innovations, in: Horbach, Jens, Joseph Huber, Thomas Schulz (Hrsg.), Nachhaltigkeit und Innovation: Rahmenbedingungen für Umweltinnovationen, München: ökonom, pp. 11-53.

Beise, Marian, Klaus Rennings (2003): Lead Markets of Environmental Innovations: A Framework for Innovation and Environmental Economics, ZEW Discussion Paper No. 03-01, Mannheim.

Beise, Marian, Klaus Rennings (2004): Environmental Policy and the Global Success of Next Generation Engine Designs, International Journal of Energy Technology and Policy (forthcoming).

Berne, Michel (1996): The Minitel Success, Paper presented at the international conference "The Social Shaping of Information Highways" Oct. 5-7. 
Binswanger, Hans, Vernon Ruttan (1978): Induced Innovation: Technology, Institutions, and Development, Baltimore, London: John Hopkins University Press.

Bresnahan, Timothy F./Franco Malerba (1999): Industrial Dynamics and the Evolution of Firms' and Nations' Competitive Capabilites in the World Computer Industry, in: D. Mowery, R. Nelson (Eds.), Sources of Industrial Leadership, Cambridge: Cambridge University Press, pp. 79-132.

Cateora, Philip R.,John L. Graham (2002): International Marketing, 11th edition, New York: McGraw-Hill.

Ceruzzi, Paul (1996): From Scientific Instrument to Everyday Application: the Emergence of Personal Computers, 1970-77, History and Technology $13,1-31$.

Cooper, Robert G., Elko J. Kleinschmidt (1987): Success Factors in Product Innovation, Industrial Marketing Management 16, pp. 215-223.

Coopersmith, Jonathan (1993): Facsimile's False Starts, IEEE spectrum, February, 46-49.

Christensen, Cylaton M. (1997): The Innovator's Dilemma: When New Technologies Cause Great Firms to Fail, Boston: Harvard Business School Press.

Dekimpe, Marnik G., Philip M. Parker, Miklos Sarvary (2000a): Globalisation: Modelling Technology Adoption Timing across Countries, Technology Forecasting and Social Change 63, pp. 25-42.

Dekimpe, Marnik G., Philip M. Parker, Miklos Sarvary (2000b): MultiMarket and Global Diffusion, in: Mahajan, V., Muller, E., Wind, Y. (Eds.), New-Product Diffusion Models, Boston et al.: Kluwer, pp. 49-74.

Dertouzos, Michael L., Richard K. Lester, Robert M. Solow (1989): Made in America: Regaining the Productivity Edge, Cambridge, Mass.: MIT Press.

Department of Trade and Industry (DTI) (1999): Moving into the Information Age: An International Benchmarking Study 1999, London.

Dosi, Giovanni (1988): Sources, Procedures and Microeconomic Effects of Innovation, Journal of Economic Literature 26, 1120-1171.

Douglas, Susan P., Yoram Wind (1987): The Myth of Globalisation, Columbia Journal of World Business 22 (Winter), 19-29.

Economides, Nicholas, Charles Himmelberg (1995): Critical Mass and Network Size with Application to the US FAX Market, Working Paper 95-11, New York University. 
Fagerberg, Jan (1992): The Home Market Hypothesis Re-examined: The Impact of Domestic User-Producer Interaction on Export Specialisation, in: B.-A. Lundvall (ed.), National Systems of Innovation, London, New York: Pinter, pp. 226-239.

Fagerberg, Jan (1995): User-Producer Interaction, Learning and Comparative Advantage, Cambridge Journal of Economics 19, 243-256.

Franko, Lawrence G. (1976): The European Multinationals, London: Harper \& Row.

Freeman, Christopher, Luc Soete (1997): The Economics of Industrial Innovation, 3rd Edition, Cambridge: MIT Press.

Freiberger, Paul, Michael Swaine (1984): Fire in the Valley: The Making of the Personal Computer, Berkeley: Osborne/McGraw-Hill.

Freeman, Chris, Luc Soete (1997): The Economics of Industrial Innovation, Cambridge: MIT Press.

Gemünden, Hans Georg (1981): Innovationsmarketing: Interaktionsbeziehungen zwischen Hersteller und Verwender innovativer Investitionsgüter, Tübingen: Mohr/Siebeck.

Gort, Michael, Steven Klepper, (1982): Time Paths in the Diffusion of Product Innovations, Economic Journal 92, 630-653.

Grossman, Gene M., Helpman, Elhanan (1991): Innovation and Growth in the Global Economy, Cambridge, London: MIT Press.

Gruner, Kjell E., Christian Homburg (2000): Does Customer Interaction enhance New Product Success?, Journal of Business Research 49, 1-14.

Grupp, Hariolf, Shlomo Maital (1998): Interpreting the Sources of Market Value in a Capital Goods Market: R\&D Management in Industrial Sensors, REDD Management 28 (2), 65-77.

Hall, Bronwyn (2004): Innovation and Diffusion, NBER Working Paper, No. 10212, Cambridge.

Hippel, Eric v. (1988): Sources of Innovation, New York: Oxford University Press.

Kern, Kristine, Helge Jörgens, Martin Jänicke (2000): Die Diffusion umweltpolitischer Innovationen: Ein Beitrag zur Globalisierung as von Umweltpolitik, Zeitschrift für Umweltpolitik \& Umweltrecht (4), 507-546.

Johansson, Johny K. (2000): Global Marketing: Foreign Entry, Local Marketing, \& Global Management, Boston et al.: Irwin McGraw Hill. 
Johanson, Jan, Jan-Eric Vahle (1977): The Internationalisation Process of the Firm - A Model of Knowledge Development and Increasing Foreign Market Commitments, Journal of International Business Studies 8 (1), 2232 .

Johnson, Chalmers (1982): MITI and the Japanese Miracle: The Growth of Industrial Policy, 1925-1975, Stanford: Stanford University Press.

Johnstone, Bob (1999): We Were Burning : Japanese Entrepreneurs and the Forging of the Electronic Age, Basic Books.

Keller, Wolfgang (1996): Absorptive Capacity : On the Creation and Acquisition of Technology in Development, it Journal of Development Economics 49 (1) (apr), 199-227.

Klemperer, Paul (1987): The Competitiveness of Markets with Switching Costs, Rand Journal of Economics 18 (1), pp. 138-150.

Kotabe, Masaaki, Kristiaan Helsen (1998): it Global Marketing Management, New York: Wiley.

Kramer, Richard (1993): The Politics of Information: A Study of the French Minitel System, in: Jorge R. Schement, Brent D. Ruben (eds.), Between Communication and Information, Information and Behavior Vol. 4, New Brunswick, London: Transaction Publ., pp. 453-486.

Krugman, Paul (1994): Location and Competition: Notes on Economic Geography, in: R. Rumelt, D. Schendel, D. Teece (eds.), Fundamental Issues in Strategy: A Research Agenda, Boston: Harvard Business School Press, pp. 463-493.

Kumar, N., N. S. Siddharthan (1994): Technology, firm size and export behaviour in developing countries: the case of Indian enterprises, Journal of Developing Studies 31: 289-309.

Levitt, Theodore (1983): The Globalisation of Markets, Harvard Business Review 61 (3), pp. 92-102.

Linder, Staffan (1961): An Essay on Trade and Transformation, Uppsala.

Lundvall, Bengt-Åke (1988): Innovation as an Interactive Process - from UserProducer Interaction to the National System of Innovation, in: G. Dosi et al. (eds.), Technical Change and Economic Theory, London: Pinter, pp. 349-369.

MacKenzie, Donald, Judy Wajcman (1999): Introductory essay: The Social Shaping of Technology, in: MacKenzie, D., Judy Wajcman (eds.), The Social Shaping of Technology, Buckingham, Philadelphia: Open University Press, pp. 64-86. 
Mansfield, Edwin (1968): Industrial Research and Technological Innovation: An Econometric Analysis, New York: Norton.

Metcalfe, Stan (1995): The Economic Foundations of Technology Policy: Equilibrium and Evolutionary Perspectives, in: P. Stoneman (ed.), Handbook of the Economics of Innovation and Technical Change, Oxford: Blackwell, pp. 409-512.

Mowery, David, Richard Nelson (eds.): Sources of Industrial Leadership, Boston: Cambridge University Press.

OECD (1968): Gaps in Technology: General Report, Paris.

OECD (1997): Communications Outlook 1997, Vol. 1, Paris.

Okimoto, Daniel (1989): Between MITI and the market : Japanese industrial policy for high technology, Stanford, Calif. : Stanford University Press.

Peterson, M.J. (1995): The Emergence of a Mass Market for Fax Machines, Technology in Society 17 (4), 469-482.

Porter, Michael E. (1986): Changing Patterns of International Competition, California Management Review 28, 9-40.

Porter, Michael E. (1990): The Competitive Advantage of Nations, New York: Free Press.

Posner, Michael V. (1961): International Trade and Technical Change, $O x$ ford Economic Papers 30: 323-341.

Reuveny, Rafael, William R. Thompson (2001): Leading Sectors, Lead Economies, and Economic Growth, Review of International Political Economy 8 (4), 689-719.

Robinson, William, Claes Fornell (1985): Sources of Market Pioneer Advantage in Consumer Goods Industries, Journal of Marketing Research 22, 305-317.

Rothwell, Richard, Christopher Freeman, et al. (1974): Sappho Updated - Project Sappho Phase II, Research Policy 3, 204-225.

Sakakibara, Mariko, Michael E. Porter (2001): Competing at home to win abroad: Evidence from Japanese Industry, Review of Economics and Statistics 83(2), 310-322.

Scherer, Frederic M. (1992): International High-Technology Competition, Cambridge: Harvard University Press.

Schmookler, Jacob (1966): Invention and Growth, Cambridge: Harvard University Press. 
Tilton, John, E. (1971): International Diffusion of Technology: The Case of Semiconductors, Washington, D.C.: The Brookings Institution.

Tsuru, Shigeto (1993): Japan's capitalism: creative defeat and beyond, Cambridge: Cambridge University Press.

Utterback, James M. (1994): Mastering the Dynamics of Innovation, Boston: Harvard Business School Press.

Vernon, Raymond (1966): International Investment and International Trade in the Product Cycle, Quarterly Review of Economics 88: 190-207.

Vernon, Raymond (1979): The Product Cycle Hypothesis in a New International Environment, Oxford Bulletin of Economics and Statistics 41 (4), $255-267$.

Womack, James, Daniel T. Jones, Daniel Roos (1990): The Machine That Changed the World: The Story of Lean Production, New York: Rawson Associates.

Yoffie, David B. (ed.) (1997): Competing in the Age of Digital Convergence, Boston, Mass.: Harvard Business School Press. 